\title{
TREE-CLIMBING BY LONG-TAILED WEASEL: AN ANTI-PREDATOR STRATEGY?
}

\section{DICK DEKKER, 3819 - 112A Street, Edmonton, Alberta. T6J 1 K4}

On 9 September 1990, while walking westward along a road allowance near Beaverhill Lake, Alberta, I noted a Long-tailed Weasel (Mustela frenata) upright in the grassy ditch, about $30 \mathrm{~m}$ ahead. After watching it through binoculars for a few moments, I proceeded further along the road. Immediately, the weasel ran east along the ditch for about $10 \mathrm{~m}$ and jumped onto the trunk of a lone willow tree growing on the edge of the ditch at a location between myself and the point where the weasel had first been observed. The weasel climbed very quickly to a height of about $3 \mathrm{~m}$. At my close approach, the weasel moved higher up into the top branches. Eventually, the weasel sat motionless, without making any sound, looking boldly down at me standing just $2 \mathrm{~m}$ below. The animal appeared to be an adult with an estimated total length of $45 \mathrm{~cm}$ including a tail of $15-18 \mathrm{~cm}$.

I have seen weasels in willow trees on two previous occasions in the same general area. Tree climbing by Ermine (Mustela erminea) was reported by Soper. ${ }^{7}$ Banfield stated that, "Ermine can climb well and often pursue squirrels and chipmunks in trees." However, in my opinion, weasels may ascend trees for a totally different reason: to escape from ground predators. Evidently, the Long-tailed Weasel seen on 9 September fled to the willow tree because of my approach. Trees can provide refuge from large carnivores such as foxes or coyotes. Tree climbing to escape from canid pursuers is known of cats, both domestic and wild. American Martens (Martes americana) are arboreal members of the Mustelid family. Less well known is the fact that even mink may ascend trees when pressed hard by pursuers. On a November day in 1968, after Beaverhill Lake was frozen, I ran after an American Mink (Mustela vison) that fled across a snow-covered pasture. The animal eventually jumped onto the trunk of a poplar tree and climbed high into the branches.

The Prairie Long-tailed Weasel ( $M$. f. longicauda) has become quite a rare animal on the central Canadian plains. In 1982 it was listed as threatened by the Committee on the Status of Endangered Wildlife in Canada (COSEWIC). ${ }^{2}$ It is my contention that this weasel's rarity may in part be due to direct predation by wild canids, particularly the Coyote. During the last two decades, perhaps due to reduced controls, the Coyotes have thrived in central Alberta and probably elsewhere on the Canadian plains. In addition, Red Foxes now occupy pockets of prairie habitat near farms and roads that were formerly unoccupied by wild canids. $^{3,4}$ 
Foxes are known to be mortal enemies of weasels although they seldom eat the weasels. The carcasses of small Mustelids have often been found around fox dens, and field studies in Pennsylvania have provided conclusive proof that foxes are capable of reducing and controlling weasel populations. ${ }^{5}$ In the Netherlands, weasels were extirpated in coastal dunes after introduced Red Foxes became numerous. ${ }^{6}$

Most naturalists support the notion that wild predators should be essentially unmanaged by man. However, it should be remembered that the larger predators are often intolerant of smaller predators. Since the 1970s, Long-tailed Weasels appear to have become very scarce on pastures around Beaverhill Lake. Also jack rabbits have become rare compared to earlier years. There is no doubt that Coyote populations are high. During afternoon walks in winter and early spring, it is routine to see two to eight Coyotes, and in the evening their howling chorus can be heard from several directions at once. It is my opinion that we pay a price for having so many Coyotes around: the scarcity or local extirpation of smaller predators such as weasels.

1. BANFIELD, A.W.F. 1974. The mammals of Canada. Univ. of Toronto Press, Toronto. $438 \mathrm{pp}$.

2. COURTNEY, R.F. and N.J. SMITH. 1988. Identifying Long-tailed Weasels on the prairies. Blue Jay 46:93-96.

3. DEKKER, D. 1973. Red Foxes make a come-back after 30 years. Blue Jay 31:43-44.

4. - 1983. Denning and foraging habits of Red Foxes and their interaction with Coyotes in central Alberta, 1972-1981. Can. Field-Nat. 97:303306.

5. LATHAM, R.M. 1952. The fox as a factor in the control of weasel populations. Journ. of Wild. Manage. 16:516-517.

6. MULDER, J. 1990. The Stoat (Mustela erminea) in the Dutch dune region, its local extermination a possible cause: the arrival of the fox (Vulpes vulpes). Lutra 33:1-21.

7. SOPER, J.D. 1964. The mammals of Alberta. Queen's Printer. Edmonton. $402 \mathrm{pp}$.

To the labourer in the sweat of his labour, the raw stuff on his anvil is an adversary to be conquered. So was wilderness an adversary to the pioneer.

But to the labourer in repose, able for the moment to cast a philosophical eye on the world, the same raw stuff is something to be loved and cherished, because it gives definition and meaning to his life. This is a plea for the preservation of some tag-ends of wilderness, as museum pieces, for the edification of those who may one day wish to see, feel, or study the origins of their cultural inheritance. Aldo Leopold, 1949. A Sand County Almanac. Oxford. 